\title{
CHILDREN WITH SPECIAL NEEDS IN LATVIA. LEGISLATIVE FRAME
}

\author{
Linda Daniela \\ University of Latvia
}

\begin{abstract}
The analysis of the legislative regulation which determines the rights of children with special needs and regulates their guarantee leads to the conclusion that, on the one hand, defining equal rights to all children to receive education but failing to ensure these rights to children with special needs in a place that is as much as possible close to their dwelling place, their rights to live in the family, to choose education that corresponds to their desire as well as the possibility to socialize with children who have no special needs are violated. Why such statements? They are based on the analysis of the legislative acts of the Republic of Latvia and the education possibilities offered by the municipalities.
\end{abstract}

Keywords: children with special needs, education, equal rights.

Equal rights to all people! Equal rights to all children! These are key values accepted by Latvia both by joining different international declarations and adopting the normative regulation in Latvia; however, there are still groups of people that can be considered marginal and subjected to social exclusion risk. One of such groups is children with special needs. Inclusive society and inclusive education should be an aim to be achieved.

The subject of inclusive education is every child but the object of inclusive education- the educational institution. According to UNESCO definition inclusive education is a process which ensures the satisfaction of the respective diverse needs of all learners increasing everybody's possibilities of participation in the teaching/learning process, culture and different communities and decreasing the exclusion possibilities from education and the process of acquiring education (UNESCO, 2004).The understanding of the given thought is based on the idea that regardless the ethnic origin, cultural or linguistic heritage, religion, social status, learning difficulties, behaviour problems, disabilities a. o. issues connected with the diversity it is necessary to ensure full-fledged education involving learners physically, cognitively and emotionally.

As the problem of decreasing the social exclusion is a complex phenomenon, its solution requires a complex and all-embracing approach. The authors of the conception "Development of the support system for young people subjected to social exclusion risk and inclusive education and training of the necessary staff for its implementation and improvement of quality" consider that social exclusion is a social multi-dimensional marginalization process which embodies the economic, social, cultural and political aspects and which is characterized by the inability of the individuals or groups of people fully or partly join the society when they have no or have a burdened access to such 
resources, services and activities that are vitally important for the development of the person and ensure full-bodied functioning of the person in the society. This is connected with insufficient social participation, insufficient social integration and inability to participate in the processes taking place in the society (Nimante, Daniela, et.al., 2009). According to this conception children with special needs can be considered to be directly subjected to the social exclusion risk.

The general Declaration on human rights states that every person as the member of the society has rights to social provision and the implementation of rights needed for maintaining the personal self-esteem and free development in the economic, social and cultural field with the help of national events and through international cooperation and in accordance with the structure and resources of each country (General Declaration on human rights).

In accordance with the Constitution (Satversme) of the Republic of Latvia the key human rights are presented in Chapter VIII stating that all people in Latvia are equal in front of law and court. Human rights are implemented without any discrimination (Article 91, Satversme of the Republic of Latvia, 1922). The official web page of the Ombudsman of the Republic of Latvia has a section "Social, economic and culture rights" which among others also point out the rights to education (Ombudsman of the Republic of Latvia, 2012).

According to European legal norms, which Latvia has joined, children is the category of people who are considered physically and intellectually immature persons who need special protection and care, which is determined by the Law on protecting children's rights that also states that a family is a natural environment for the child's development and that every child enjoys inalienable right to grow up in the family (Article 26, Law on protecting children's rights, 1998).Special article in the Law on protecting children's rights defines the child's rights to education and declares that the state ensures equal rights to education to all children (Article 11). The "Law on social security" (Article 4, 1995), in its turn, indicates rights to education as the social rights. The Law on social services and social assistance defines the human key needs- food, clothing, home, health care, compulsory education (Article 1, 2002).

\section{Rights to education}

Article 26 of the General Declaration on human rights states that every person has rights to education. Education, at least basic and general education should be free of charge. The basic education should be compulsory. Technical and vocational education should be accessible to all according to everyone's abilities (1948). Article 13 of the International covenant of the UNO on economic, social and cultural rights declares that the participating countries recognize every person's rights to education and basic education should be compulsory and free of charge to everybody. Article 2 of Protocol 1 of European Convention on protection of human rights and key freedoms establishes that no person should be denied the rights to education. The state performing any 
function in relation to education and learning observes the parents' rights to ensure such education and learning to their children that corresponds to their religion conviction and philosophical views (1966). It agrees with the law adopted in Latvia - "On revised European social charter" where Article 17 declares that the contracting parties undertake to ensure the possibility for children to grow in a safe and favourable environment stating in Chapter 2 that it should be done by providing free basic and secondary education to children and young people as well as promoting regular attendance of school (2013). The law on protecting children's rights points out a group of children defined as "children with special needs", which allows concluding that besides the fact that children are a group of people who deserve special care, there are children whose needs are a priority. Article 53, Chapter VIII of this law specifies that child with special needs is "a child who due to illness, trauma or disturbances of functioning of the body systems caused by an inborn defect needs additional medical, pedagogical and social help regardless whether the incapacity is defined in order stipulated by the law" (1998). The term "special needs" in the Law on general education, in its turn, is defined as the necessity to receive such support and rehabilitation that creates the possibility for learners acquire the educational curriculum taking into consideration their health conditions, abilities and development level (Article 1, 1999).

So far it is clear that the state undertakes to ensure equal rights to all children and take special care about children with special needs because also Article 12 of the Law on disability states that the disability consequences of people with disablement are decreased: 4) ensuring rights in preschool education, general basic education, vocational basic education, vocational education, general secondary education and vocational education institutions (except special education institutions that receive maintenance funding from the state budget for the learners - people with disabilities) to receive from the state paid services of the assistant for supporting moving and self-care; 5) ensuring rights to receive from the state budget the services of a paidsurdo-interpreter for the acquisition of the educational curriculum; 10) implementing other support activities defined in legislative documents.

It agrees with the ideas emphasized in part 3, Article 15 of the "Revised European social charter" that in order to ensure the rights of disabled people and mentally retarded people and to ensure their full integration and participation in public life, mainly carrying out activities, including activities in technical field, purposefully overcoming the barriers in the field of communication and movement creating access to transport vehicles, dwelling places, cultural events and free time activities (2013). The Law on education defines that people with special needs receive special education (special education- general and vocational education adapted for people with special needs and health disturbances or special needs, or health disturbances) (Article 1, Para. 24, 1998). Chapter VIII of the Law on general education enumerates all kinds of special 
education and states that special education programs ensure a possibility for learners with acquired or inborn functional disturbances to acquire general education according to their special needs (1998). The above mentioned legislative documents serve as a confirmation that Latvia has envisaged a definite order how to ensure the rights and needs of children, including children with special needs, to receive education and has delegated the organizational function to municipalities.

Article 15 of the Law "On municipalities" about the autonomous functions of the municipality mentions "to care for the inhabitants' education (ensuring the rights to basic education and general secondary education established for the inhabitants, ensuring a place in the educational institution for preschool and school age children, organizational and financial assistance to out-of-school educational institutions and education support institutions, etc.) (1994) as one of them, which agrees with the responsibility of the municipalities defined in the Law on education to ensure children with special needs (according to their health condition that influences the kind of acquiring education) in special education institutions, preschool education groups for children with special needs, special education classes as well as in boarding schools in order and scope defined by the Council of Ministers". It means that municipalities have the main responsibility about ensuring education for children with special needs. Thus it is possible to conclude that the municipality organizes education envisaging that everyone can receive education corresponding to his individual needs.

And here complications emerge because the duty of the municipality is to take care of all children and if a child living in the administrative territory of the municipality is diagnosed special needs but the educational institutions of the municipality does not have a licensed educational program corresponding to the specifics of these needs then the solutions often do not serve the child's interest to grow up in the family and receive all the necessary support that the state guarantees. The traditional practice is that children with special needs are sent to attend educational institutions which implement such programs thus formally these needs are met but at the same time if, for example, the child with behavioural disturbances lives in the territory of the municipality which does not have such an educational institution that has licensed the educational program for children with behavioural disturbances then the traditional solution is to send the child to another place of Latvia in order to ensure the child corresponding education. Children with behavioural disturbances according to the regulations of the Council of Ministers Nr. 710(Regulations on provisions of general basic education and secondary education institutions according to learners' special needs, 2012) have the respective program for "learners with health disturbances" and in Latvia there are 15 such programs available (National data base of Learning opportunities). In Latvia there are 109 municipalities so we can conclude that in case the child with such disturbances lives in the administrative 
territory of the municipality where there is no such program then the municipality performing its duty and trying to ensure the child's rights to education according to his special needs violates the principle which is established in the Law on protecting children's rights and the Law on social security that the child has the rights to grow in the family and these rights should be supported. This separation from the family creates additional emotional strain to the child which influences his intellectual achievements. This means that the child who has serious health problems is torn away from his family, his environment and he spends most of the time in an unfamiliar place, with unknown people who are not his relatives. This allows concluding that this system contradicts the principles of the inclusive society. Children with special needs live in segregated environments, failing to learn from the childhood to live in the society and also to learn cooperating with people who have different special needs.

Parents who are not ready for such a solution that the child has to spend time outside the family for a long time search for other different solutions - they organize home teaching that is envisaged by the regulations of the Council of Ministers Nr. 253 „Order in which to organize education of continuously ill learners outside the educational institution" (2006). However, these regulations envisage that such education at home is possible for 6 months which can be prolonged checking the child's health repeatedly, but it can be only short time solution. These regulations anticipate that the child who is learning at home needs the individual learning plan and it is provided that a teacher visits the child at home but it still means that the child does not socialize.

Or, for example, sometimes children with severe visual problems continue attending the mainstream educational institutions which do not have corresponding learning support materials (materials with larger letters, touchable materials, etc.), no licensed educational programs and teachers who have been specifically trained thus the child's intellectual development is not facilitated. This allows concluding that none of the traditional solutions offered by the municipality is favourable for the child's full-fledged development.

The same problems are topical also for children with different other diagnoses, all in all 10 different groups of diagnoses that have been enlisted in the regulations of pedagogically medical commissions (Regulations of the Council of Ministers Nr.709 „On pedagogically medical commissions, 2012). The Law on general education states that the head of the educational institution is responsible for gathering information about the special needs of the learners and their education according to the special education programs (Para.3, Part 2, Article 11). Some municipalities have already started solving this problem licensing the educational programs that are implemented by the educational institutions under their supervision corresponding to the special needs of children living in the municipality because when implementing the principle "money follows the child" municipalities have started to calculate also the 
financial expenses about sending the child to schools registered in other municipalities. Regulations of the Council of Ministers Nr. 710 define the provisions needed to integrate children with special needs in mainstream educational institutions (Regulations on provisions of general basic education and secondary education institutions according to learners' special needs, 2012).

If we analyse these legislative documents then we get the impression that there should be no problems connected with the accessibility to education; however, also here there are contradictions with what has been defined by the Law on disability for people with hearing disorders, namely, that a person who acquires the educational program in a vocational basic education institution, vocational secondary education or higher education institution has the right to receive the services of the surdo-interpreter if his hearing disturbances cannot be compensated with technical remedy aids (Article 13, Law on disability, 2010). This could mean that children who want to integrate in general comprehensive schools have no access to such services. To be more precise, this is not guaranteed by the state. Regulations of the Council of Ministers Nr. 942 on the order about conditions for providing the assistant, Appendix 1 about the criteria for ensuring the services of the assistant mentions cases when the assistant's services are available and states that one can claim such services if he attends general education or vocational education institution or studies in a higher education institution. But in this case the assistant's duty is to help to get to and to return from the educational institution and not exceeding 10 hours per week. Thus, we can conclude that the assistant is envisaged for getting to the educational institution but his service is not envisaged for helping the child while at the school (Order in which assistant's services are assigned and funded in the municipality, 2012). The assistant's service in the educational institution is regulated by other regulations of the Council of Ministers Nr. 695 (Order in which assistant's services are assigned and funded in the educational institution, 2012) but also they are based on the Law on disability which define that visually impaired people can be provided with an assistant if they acquire the educational program in vocational basic education, vocational secondary education or higher education institution (Part 1, Article 13). Summarizing all the above said it is possible to conclude that the assistant's services in preschools and general comprehensive basic schools are accessible to children with different functional disorders that influence their moving from place to place, to children with mental disorders but they are not accessible to visually impaired children as well as the services of the surdo-interpreter are not available to children with hearing disorders. Thus we can conclude that also the social rights of children with sight and hearing disorders to receive education closer to their living place and grow in the family are, to a certain extent, limited.

Another problem group is the preschool children who have special needs. Law on general education states that the municipality can establish a special preschool if there are no less than 8 children with special needs if it is demanded 
by parents (Article 25, Law on general education). This creates a number of new problems because not always there are 8 children of the particular special needs group and if they are children with different special needs then it complicates the possibilities of the staff to provide the respective support in the pedagogical process. These problems indicate the necessity for municipalities to seek solutions for licensing integrated educational problems also for preschool children.

According to regulations of the Council of Ministers Nr. 709 about the pedagogical commissions one of their responsibilities is to promote the integration of children with special needs living in the administrative territory of the municipality in the general comprehensive educational institutions situated in the administrative territory of the municipality. As it has been mentioned above, the legislative documents of the Republic of Latvia state that it is possible to license 10 different special education programs that correspond to children's special needs. Analysing the publicly accessible information about the licensed educational programs in Latvia (National data base of Learning opportunities) it is possible to make a summary which indicates that the most programs are available to children with mental developmental disturbances and children with learning disorders. The educational programs corresponding to other groups of special needs are licensed considerably less than there are municipalities in Latvia which allows concluding that the above given statements that all children in Latvia are not provided equal rights are true and there is still a long way to go in order to ensure fully the implementation of the principles of inclusive education in the education system of Latvia (see Table 1).

Table 1. Special basic education programs in Latvia (based on data from National data base of Learning opportunities)

\begin{tabular}{|l|c|}
\hline Special basic education programs & number \\
\hline \hline Visually impaired learners & 7 \\
\hline \hline Hearing impaired learners & 9 \\
\hline \hline Learners with disturbances of physical development & 19 \\
\hline \hline Learners with somatic diseases & 14 \\
\hline \hline Learners with language disturbances & 20 \\
\hline \hline Learners with learning difficulties & 224 \\
\hline \hline Learners with mental health disturbances & 15 \\
\hline \hline Learners with mental developmental disturbances & 302 \\
\hline \hline $\begin{array}{l}\text { Learners with serious mental developmental disturbances or several serious } \\
\text { developmental disturbances }\end{array}$ & 69 \\
\hline \hline
\end{tabular}


Four different municipalities of Latvia were chosen for a more profound analysis - a regional municipality (1) that is situated rather far from the capital of Latvia. It includes 25 rural regions which means that this municipality is one of the largest in Latvia as to the territory and the largest number of rural regions that are included in this municipality. The second is the regional municipality (2) that is situated in the opposite part of Latvia and is approximately as large as the previous one included in the analysis though it has only 14 rural regions; the third chosen is the municipality (3) that is comparatively smaller but is situated rather close to Riga which could mean that the services are more accessible than in the municipalities that are further away. The fourth chosen is the municipality (4) of a large town. All these municipalities are different and the obtained results are summarized in Table 2. The findings allow concluding that there are municipalities which ensure the respective educational programs to only some groups of children with special needs in the administrative territory of the municipality and this confirms the above expressed assumption that the rights of all children are not satisfied equally.

Table 2. Comparison of provided special basic education program sinanlysed municipalities

\begin{tabular}{|c|c|c|c|c|c|}
\hline \multicolumn{2}{|c|}{ Special basic education programs } & \multirow[t]{2}{*}{1} & \multirow[t]{2}{*}{2} & \multirow[t]{2}{*}{3} & \multirow[t]{2}{*}{4} \\
\hline 1. & Visually impaired learners & & & & \\
\hline 2. & Hearing impaired learners & & & & \\
\hline 3. & Learners with disturbances of physical development & 1 & & & \\
\hline 4. & Learners with somatic diseases & & & & \\
\hline 5. & Learners with language disturbances & 1 & 1 & & \\
\hline 6. & Learners with learning difficulties & 11 & 1 & 5 & 3 \\
\hline 7. & Learners with mental health disturbances & 4 & & & \\
\hline 8. & Learners with mental developmental disturbances & 16 & 1 & 3 & 2 \\
\hline 9. & $\begin{array}{l}\text { Learners with serious mental developmental disturbances or } \\
\text { several serious developmental disturbances }\end{array}$ & 1 & 1 & 1 & 3 \\
\hline
\end{tabular}

\section{Possible solutions:}

- To license special education programs in the municipalities for children living in these municipalities who have some special needs and to organize an integrated teaching/learning process (children with special needs learn together with other children). This possibility is envisaged by the Law on general education 1) paragraph of Article 53 - Learners with special needs can be integrated in general basic 
education and secondary education institutions that have the corresponding provisions (Article 53).

- To prepare teachers of general comprehensive schools and preschools for work with children with special needs concentrating on those needs that are topical for children living in the municipality. This is envisaged by the regulations of the Council of Ministers on pedagogically medical commissions - to consult teachers, parents and other people on the issues of special education (Regulations of the Council of Ministers No 709, Regulations on pedagogically medical commissions), which means that such kind of organisation of educational process is possible.

- To organize a possibility for the municipality educational institutions to hire learning support materials (computers with special programs, magnifying glasses, slate pencils, etc.) that correspond to the diagnosis for the period of time while the child is attending the particular educational institution. This should be well-considered because these support materials are very expensive and it would be irrational for schools to purchase them because as the child with special needs grows up the school will no longer need these materials. According to 2) paragraph of Article 53 of the Law on general education the availability of corresponding support activities for learners with special needs who are integrated in the general comprehensive school are provided by the educational institution. The educational institution develops an individual plan for acquiring the educational program for each integrated learner with special needs (Article 53).

\section{Conclusions}

\section{child: \\ The current order in Latvia does not ensure equal rights to every}

1. The rights to grow up in the family, which are violated because failing to provide the acquisition of education that corresponds to the child's special needs in the educational institution where the child has to stay for a long period of time violates the child's rights to grow up in the family that the state undertakes to ensure as a priority. Article 26 of the Law on protecting children's rights defines that family is a natural environment for the child's development and growing, and that every child has inalienable rights to grow up in the family. The Law on municipalities establishes that the responsibility of the municipality is also to implement the protection of children's rights in the respective administrative territory which indicates also the necessity not only to organize the acquisition of education but to organize it so that the 
child's key rights are respected and he is not discriminated due to his special needs.

2. The rights to socialize - they are defined in the law "On revised European social charter" where Article 17 of Part I states that children and young people have rights to respective social, legal and economic protection but these rights of children with special needs are ensured only in segregated environment, it means, together with other children with special needs.

3. The rights to social equality, which are defined in the law "On revised European social charter" where Article 30 of Part II states that in order to ensure effective use of the rights to protection against deficiency and social inequality it is necessary to implement general and coordinated measures within the system in order to ensure persons and their families that live or are subjected to the risk of living in deficiency or in the conditions of social inequality with employment, dwelling place, training, education, culture and social and medical care that is not ensured if children with special needs are placed in the educational institutions that are not situated close to their living place.

4. Prohibition of discrimination that is established in Article 3 of the Law on protecting children's rights establishing that the state ensures all children the child's rights and freedoms without any discrimination, including the health conditions and Article 91 of Constitution (Satversme) of the Republic of Latvia states that the rights of all people are implemented without any discrimination which is not ensured in all cases in Latvia.

\section{References}

Bērnu tiesību aizsardzības likums (Law on protecting children's rights), 19.06.1998., http://likumi.lv/doc.php?id=49096

Guidelines for Inclusion, UNESCO, 2004 http://unesdoc.unesco.org/images/0014/001402/ 140224e.pdf

Invaliditātes likums (Law on disability), 20.05.2010., http://likumi.lv/doc.php?id=211494

Izglītības likums (Law on education), 29.10.1998., http://likumi.lv/doc.php?id=50759

Latvijas Republikas Satversme (Satversme (Constitution) of the Republic of Latvia), 15.02.1922., http://likumi.lv/doc.php?id=57980

LatvijasTiesibsargs (Ombudsman of the Republic of Latvia), Social and economic rights, 2012,http://www.tiesibsargs.lv/lv/socialas-un-ekonomiskas-tiesibas

Ministru kabineta noteikumi Nr.253 „Kārtība, kādā organizējama ilgstoši slimojošu izglītojamo izglītošanās ārpus izglītības iestādes" (Regulations of the Council of Ministers Nr.253 „Order in which to organize education ofcontinuously ill learners outside the educational institution"), 04.04.2006., http://likumi.lv/doc.php?id=132350

Ministru kabineta noteikumi nr. 695, Kārtība, kādā piešķir un finansē asistenta pakalpojumu izglīīibas iestādē (Regulations of the Council of Ministers Nr. 695, Order in which assistants' services are assigned and funded in the educational institution), 09.10.2012., http://likumi.lv/doc.php?id=252140 


\section{SOCIETY. INTEGRATION. EDUCATION. Volume III}

Ministru kabineta noteikumi nr. 709, Noteikumi par pedagogiski medicīniskajām komisijām (Regulations of the Council of Ministers Nr.709 On pedagogically medical commissions), 16.10.2012., http://likumi.lv/doc.php?id=252162

Ministru kabineta noteikumi nr. 710, Noteikumi par vispārējās pamatizglītības un vispārējās vidējās izglītības iestāžu nodrošinājumu atbilstoši izglītojamo speciālajām vajadzībām (Regulations of the Council of Ministers Nr. 710, Regulations on provisions of general basic education and secondary education institutions according to learners' special needs), 16.10.2012., http://likumi.lv/doc.php?id=252163

Ministru kabineta noteikumi nr. 942, Kārtība kādā piešķir un finansē asistenta pakalpojumu pašvaldībā (Regulations of the Council of Ministers Nr. 942, Order in which assistant's services are assigned and funded in the municipality), 18.12.2012., http://likumi.lv/doc.php?id=253781

National data base of Learning opportunities, http://www.niid.lv/niid_search,

Nimante, Daniela, et al., (2009). The conception of developing the support system for young people subjected to social exclusion risk and inclusive education and training of the necessary staff for its implementation and improvement of quality, http://www.ppf.lu.lv/v.3/eduinf/files/2009/ESF_koncepcija.pdf

Par pašvaldībām (Law on municipalities), 19.05.1994., http://likumi.lv/doc.php?id=57255

Par pārskatīto Eiropas sociālo hartu (Lawon revised European social charter), 14.02.2013., http://likumi.lv/doc.php?id=255022

Par sociālo drošību (Lawon social security), 07.09.1995., http://likumi.lv/doc.php?id=36850

Vispārējā cilvēktiesību deklarācija (General Declaration on human rights), 10.12.1948., http://www.humanrights.lv/doc/vispaar/vispcd.htm

Sociālo pakalpojumu un sociālās palīdzības likums (Law on social services and social assistance), 31.10.2002., http://likumi.lv/doc.php?id=68488

Starptautiskais pakts par ekonomiskajām, sociālajām un kultūras tiesībām (International covenant on economic, social and cultural rights), 1966.gads, http://www.humanrights.lv/doc/vispaar/escpakc.htm,

Vispārējās izglītības likums (Law on general education), 10.06.1999., http://likumi.lv/doc.php?id=20243 